\title{
PENGARUH MODEL PEMBELAJARAN INKUIRI TERBIMBING TERHADAP KETERAMPILAN BERPIKIR KRITIS SISWA SMA
}

\author{
Asister Fernando Siagian \\ FKIP Universitas HKBP Nommensen \\ aasisterf.siagian@yahoo.com
}

\begin{abstract}
Abstrak
Penelitian ini bertujuan: Untuk Mengetahui apakah ada perbedaan model pembelajaran inkuiri terbimbing dan pembelajaran konvensional terhadap kemampuan berpikir kritis siswa. Sampel dalam penelitian ini dilakukan secara random sampling sebanyak dua kelas, dimana kelas pertama sebagai kelas eksperimen diterapkan model pembelajaran inkuiri terbimbing dan kelas kedua sebagai kelas kontrol diterapkan pembelajaran konvensional. Instrumen yang digunakan dalam penelitian ini yaitu instrumen tes kemampuan berpikir kritis dalam bentuk uraian sebanyak 4 soal yang telah dinyatakan valid dan reliabel. Dari hasil penelitian dapat disimpulkan bahwa ada pengaruh model pembelajaran inkuiri terbimbing dan pembelajaran konvensional terhadap kemampuan berpikir kritis siswa, Kemampuan berpikir kritis siswa yang diajarkan dengan model pembelajaran inkuiri terbimbing lebih baik dari pembelajaran konvensional.
\end{abstract}

Kata Kunci: inkuiri terbimbing dan keterampilan berpikir kritis

\section{EFFECT OF LEARNING MODEL GUIDED INQUIRY \\ ON CRITICAL THINKING SKILLS HIGH SCHOOL STUDENT}

\begin{abstract}
This study aims: To determine whether there are differences guided inquiry learning model and conventional learning to students' critical thinking skills. The sample in this study conducted by random sampling of two classes, where the class is first applied as an experimental class guided inquiry learning model and the second class as class applied to the conventional learning control. The instrument used in this study are critical thinking skills test instruments in the form of descriptions of 4 questions that have been declared valid and reliable. From the results of this study concluded that there is the influence of guided inquiry learning model and conventional learning to students' critical thinking skills, critical thinking skills of students who are taught by guided inquiry learning model is better than conventional learning.
\end{abstract}

Keywords: guided inquiry and critical thinking skills 


\section{PENDAHULUAN}

Fisika merupakan ilmu universal dan merupakan salah satu ilmu yang mendasari perkembangan kemajuan sains dan teknologi. Pembelajaran fisika diharapkan dapat memberikan pengalaman langsung kepada siswa untuk memahami fisika secara ilmiah. Fisika merupakan bagian dari Ilmu Pengetahuan Alam (IPA) yang merupakan hasil pengalaman langsung dari suatu gejala alam, membahas fenomena yang terjadi pada masalah-masalah nyata yang ada di alam, sehingga pembelajaran fisika bukan hanya penguasaan berupa fakta, konsep dan prinsip tetapi juga suatu proses penemuan sistematis yang harus ditempuh siswa dalam menyelesaikan suatu masalah. Dalam proses pembelajaran fisika harus menekankan kepada siswa sebagai insan yang memiliki potensi untuk belajar dan berkembang, dan siswa terlibat secara aktif dalam pencarian dan pembentukan pengetahuan oleh diri mereka sendiri. Melalui belajar fisika, siswa mendapatkan kesempatan untuk mengembangkan keterampilan proses sains, berpikir sistematis, logis dan kritis dalam mengkomunikasikan gagasan atau penyelesaian dari suatu permasalahan fisika yang dihadapi. Proses berpikir kompleks dikenal sebagai proses berpikir tingkat tinggi. Proses berpikir kompleks meliputi empat kelompok, yakni pemecahan masalah, membuat keputusan, berpikir kritis dan berpikir kreatif Costa (1985). Pengertian berpikir kritis adalah kemampuan untuk mengorganisasi, menganalisis dan mengevaluasi argumen, proses mental, strategi dan representasi seseorang yang digunakan untuk memecahkan masalah, membuat keputusan dan mempelajari konsep baru, dan cara berpikir reflektif yang masuk akal atau berdasarkan nalar yang difokuskan untuk menentukan apa yang akan dikerjakan dan diyakini (Ennis, 1996).

Berdasarkan uraian di atas aspek berpikir kritis merupakan kompetensi yang harus dimiliki siswa sebagai standar yang harus dikembangkan. Agar terjadi 
pengkontruksian pengetahuan secara bermakna, guru haruslah melatih siswa agar berpikir secara kritis dalam menganalisis maupun dalam memecahkan suatu permasalahan. Siswa yang berpikir kritis adalah siswa yang mampu mengidentifikasi, mengevaluasi dan mengkontruksi argumen serta mampu memecahkan masalah dengan tepat. Siswa yang berpikir kritis akan mampu menolong dirinya atau orang lain dalam memecahkan permasalahan yang dihadapi.

Berpikir kritis menurut Angelo (1995) merupakan kemampuan untuk mengorganisasi, menganalisis dan mengevaluasi argumen, proses mental, strategi dan representasi seseorang yang digunakan untuk memecahkan masalah, membuat keputusan dan mempelajari konsep baru, dan cara berpikir reflektif yang masuk akal atau berdasarkan nalar yang difokuskan untuk menentukan apa yang akan dikerjakan dan diyakini. Kemampuan berpikir kritis merupakan kemampuan yang akan digunakan untuk mengintegrasikan konsep yang diterima dari proses pembelajaran di sekolah dengan masalah yang akan dihadapi pada kehidupan seharihari. Oleh karena itu, sekolah sebaiknya tidak hanya menekankan pada pemahaman konsep siswa tetapi juga keterampilan berpikirnya.

Fisika juga adalah ilmu pengetahuan yang menggunakan metode ilmiah dalam prosesnya. Dengan demikian maka proses pembelajaran fisika bukan hanya memahami konsep-konsep fisika semata, melainkan juga mengajar siswa berpikir konstruktif melalui fisika sebagai keterampilan berpikir kritis, sehingga pemahaman siswa terhadap hakikat fisika menjadi utuh, baik sebagai proses maupun sebagai produk.

Kenyataan yang dapat dilihat dalam dunia pendidikan yang sedang berjalan pada saat ini bahwa keterampilan berpikir kritis siswa masih rendah. Dimana guru hanya menekankan kepada hapalan terhadap rumus fisika dan siswa tidak pernah dilibatkan dalam melakukan eksperimen. Inilah yang menjadi salah satu penyebab rendahnya mutu pendidikan di Indonesia terutama dalam mata pelajaran fisika.

Kenyataan yang mengatakan bahwa "mutu pendidikan Indonesia terutama dalam mata pelajaran fisika masih rendah". Adapun data yang mendukung hal tersebut adalah data The Trends in Internasional Mathematics and Science Study (TIMSS) menyebutkan siswa Indonesia hanya mampu menjawab konsep dasar atau hapalan dan tidak mampu menjawab soal yang 
memerlukan nalar dan analisis. Untuk bidang sains Tahun 2003 Indonesia menempati peringkat 37 dari 46 negara dan tahun 2007 Indonesia menempati peringkat 35 dari 49 negara (Efendi, 2010).

Rendahnya hasil belajar fisika didukung dengan hasil observasi yang dilakukan di SMA Swasta Kartika Pematangsiantar, pembelajaran yang digunakan oleh guru fisika selama ini cenderung menggunakan pembelajaran konvensional yang berpusat pada guru dengan urutan ceramah, tanya jawab dan penugasan menyebabkan pembelajaran kurang bermakna. Berdasarkan studi dokumentasi di sekolah tersebut menunjukkan nilai rata-rata ujian siswa baik semester ganjil maupun genap untuk mata pelajaran fisika masih rendah. Berdasarkan Daftar Kumpulan Nilai (DKN) T.P. 2013/2014 siswa kelas X untuk semester I yaitu 65,05 dan untuk semester II yaitu 65,67 dengan Kriteria Ketuntasan Minimal (KKM) disekolah tersebut adalah 67.

Rendahnya hasil belajar fisika antara lain diukur dari rendahnya keterampilan berpikir kritis. Padahal keterampilan berpikir kritis sangat penting untuk meningkatkan hasil belajar siswa. Banyak faktor yang menjadi penyebab rendahnya hasil belajar khususnya berpikir kritis salah satunya adalah dalam proses belajar mengajar, guru mengajarkan konsep melalui kegiatan yang kurang berpusat pada siswa. Siswa tidak dilibatkan secara aktif sehingga kurang memberikan kesempatan untuk mengembangkan proses berpikirnya. Selain itu pembelajaran fisika belum bermakna, bersusun dan tidak menekankan pada berpikir kritis, sehingga keterampilan fisika siswa masih rendah. Hal tersebut juga merupakan salah satu yang menyebabkan isi pembelajaran fisika dianggap sebagai hapalan, sehingga siswa tidak memiliki keterampilan berpikir kritis. Siswa yang belajar dengan hapalan tingkat kebermaknaannya akan rendah.

Hal lain yang merupakan salah satu faktor kekurang-tertarikan peserta didik adalah suasana kelas yang pasif serta sebagian peserta didik terlanjur menganggap bahwa fisika adalah pelajaran yang sulit sehingga kecenderungan kelas menjadi tegang, karena itulah diperlukan guru yang aktif dan kreatif dalam kegiatan pembelajaran juga model pembelajaran untuk meningkatkan keterampilan berpikir kritis. Maka dengan disahkannya kurikulum yang berlaku pada saat ini, diperlukan model pembelajaran yang dapat menunjang tercapainya visi kurikulum. 
Salah satu model yang ditenggarai efektif meningkatkan keterampilan berpikir kritis adalah model pembelajaran inkuiri terbimbing. Menurut Trowbrige \& Bybee (1990) "inkuiri terbimbing adalah proses menemukan dan menyelidiki masalahmasalah, menyusun hipotesis, merencanakan eksperimen, mengumpulkan data dan menarik kesimpulan data serta menarik kesimpulan tentang hasil masalah. Siswa harus membangun sendiri pengetahuan di dalam benaknya. Guru dapat memberikan kemudahan untuk proses ini, dengan memberi kesempatan siswa untuk menemukan atau menerapkan ide-ide sendiri, dan mengajar siswa menjadi sadar dan secara sadar menggunakan strategi mereka sendiri untuk belajar. Tujuan utama model inkuiri adalah mengembangkan keterampilan intelektual, berfikir kritis, dan keterampilan proses sains.

\section{METODE PENELITIAN}

Penelitian ini dilakukan di SMA Swasta Kartika Pematangsiantar, pada semester genap bulan Maret Tahun Pelajaran 2014/2015. Populasi dalam penelitian ini adalah seluruh siswa kelas $\mathrm{X}$ semester II SMA Swasta Kartika Pematangsiantar yang berjumlah 4 (empat) kelas. Masing-masing kelas terdiri dari 38 siswa dengan total populasi berjumlah 152 siswa. Sampel dalam penelitian ini adalah siswa SMA Swasta Kartika Pematangsiantar kelas $\mathrm{X}$ dengan metode pengambilan sampel adalah metode random (probability sampling), dimana pemilihan sampel tidak dilakukan secara subyektif, dalam arti sampel yang terpilih tidak didasarkan pada keinginan peneliti, sehingga setiap anggota sampel memiliki kesempatan yang sama (acak) untuk terpilih sebagai sampel (Sugiharto, 2001). Pemilihan dilakukan dengan cara undian sehingga diperoleh SMA Swasta Kartika Pematangsiantar kelas $\mathrm{X}$ yang terdiri dari dua kelas yaitu kelas $\mathrm{X}-2$ sebagai kelas kontrol dan kelas X-1 sebagai kelas eksperimen.

Variabel dalam penelitian ini ditinjau dari peranannya, terdiri atas variabel bebas dan variabel terikat. Yang menjadi variabel bebas dalam penelitian ini adalah model pembelajaran inkuiri terbimbing. Variabel terikat dalam penelitian ini adalah keterampilan berpikir kritis siswa.

Penelitian ini termasuk jenis penelitian quasi eksperimen, yaitu merupakan penelitian yang bertujuan untuk mengetahui akibat dari "sesuatu" yang dikenakan pada "subyek" yaitu siswa. Penelitian ini melibatkan dua kelas sampel yang diberi perlakuan yang berbeda. Pada kelas eksperimen dengan model 
pembelajaran inkuiri terbimbing sedangkan kelas kontrol dengan model pembelajaran konvensional. Desain penelitiannya berupa Two Group Pretes-Postes Design.

Instrumen test yang digunakan dalam penelitian ini adalah tes prestasi dengan bentuk test uraian dengan indikator tes sesuai dengan indikator keterampilan berpikir kritis. Adapun indikator bentuk soal adalah keterampilan menganalisis, keterampilan mensintesis, keterampilan memecahkan masalah dan keterampilan membuat kesimpulan.

\section{HASIL DAN PEMBAHASAN}

\section{Pretes Keterampilan Berpikir Kritis}

Deskripsi data yang disajikan dalam penelitian ini terdiri dari nilai keterampilan berpikir kritis kelas kontrol dan kelas eksperimen. Pada tahapan penelitian ini kedua kelas sampel yaitu kelas eksperimen diajarkan dengan pembelajaran inkuiri terbimbing dan kelas kontrol diajarkan dengan pembelajaran konvensional diberikan tes keterampilan berpikir kritis untuk melihat apakah kedua kelas kemampuan awal yang sama dengan melakukan uji-t dengan syarat data terdistribusi normal dan homogen. Kesamaan kemampuan awal dari kedua sampel perlu dilihat terlebih dahulu agar saat kedua kelas diberi perlakuan (treatment) dapat diperoleh perbedaan hasil belajar yang signifikan dari kemampuan awal yang sama. Adapun data pretes keterampilan berpikir kritis kelas kontrol dan kelas eksperimen dapat dilihat pada Gambar 1.

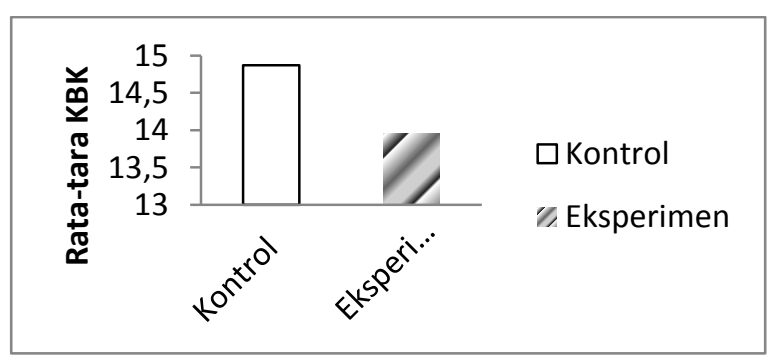

Gambar 1. Grafik Pretes Keterampilan Berpikir Kritis Kelas Kontrol dan Eksperimen.

Sebagai uji prasyarat sebelum uji $\mathrm{t}$ dilakukan uji normalitas untuk mengetahui kedua kelas berdistribusi secara normal dengan menggunakan SPSS 16.0. Uji normalitas hasil belajar tersebut dapat dilihat pada Tabel 1.

Tabel 1. Uji Normalitas Pretes Keterampilan Berpikir Kritis

\begin{tabular}{|c|c|c|c|c|c|}
\hline No & Kelas & $\begin{array}{c}\text { L- } \\
\text { hitung }\end{array}$ & Sig. & L & \\
\hline 1 & Kontrol & 0,142 & 0,051 & 0,174 & Ket. \\
\hline 2 & Eksperimen & 0,118 & 0,199 & 0,174 & Normal \\
\hline
\end{tabular}
Kelas kontrol keterampilan berpikir kritis diperoleh nilai $L_{\text {hitung }}$ sebesar 0,142 dan signifikansi sebesar $0,051 \quad\left(\mathrm{~L}_{\text {tabel }}=\right.$ $0,174, \alpha=0,05)$. Hasil ini menunjukkan 
bahwa $\mathrm{L}_{\text {hitung }}<\mathrm{L}_{\text {tabel }}$ dan signifikansi lebih besar dari 0,05, maka data pada kelas kontrol adalah berdistribusi normal.

Uji kesamaan varians dan rata-rata nilai pretes dilakukan dengan test of homogenety of variance menggunakan SPSS 16.0. Hasil pengujian dapat ditunjukkan pada Tabel 2.

Tabel 2. Uji Homogenitas Pretes Keterampilan Berpikir Kritis

\begin{tabular}{|l|l|l|l|l|}
\hline $\begin{array}{l}\text { Uji } \\
\text { Homogenitas }\end{array}$ & $\mathbf{F}_{\text {hitung }}$ & $\mathbf{F}_{\text {tabel }}$ & Sig & Keterangan \\
\hline $\begin{array}{c}\text { Berdasarkan } \\
\text { rerata }\end{array}$ & 0,105 & 1.90 & 0,747 & Homogen \\
\hline
\end{tabular}

Hasil pengujian memperlihatkan nilai $F_{\text {hitung }}$ untuk pretes keterampilan berpikir kritis 0,105 dengan signifikansi $0,747\left(\mathrm{~F}_{\text {tabel }}=1,90, \alpha=0,05\right)$. Berdasarkan hasil tersebut $\mathrm{F}_{\text {hitung }}<\mathrm{F}$ tabel dan signifikan hitung lebih besar dibandingkan $\alpha=0,05$ sehingga dapat disimpulkan data pretes keterampilan berpikir kritis kelas kontrol dan kelas eksperimen memiliki varians yang sama atau homogen. Uji normalitas dan uji homogenitas dari kedua kelas sampel dibutuhkan sebagai uji prasyarat untuk melakukan uji kesamaan pretes keterampilan berpikir kritis (uji-t). Karena data kedua kelas normal dan homogen maka dapat dilakukan uji kesamaan pretes dari kedua kelas sampel.
Uji kesamaan varians dan rata-rata nilai pretes dilakukan dengan uji t dengan menggunakan SPSS 16.0. Hasil pengujian dapat ditunjukkan pada Tabel 3.

Tabel 3. Uji Kesamaan Pretes Keterampilan Berpikir Kritis Kelas Eksperimen dan Kelas Kontrol

\begin{tabular}{|c|c|c|c|c|}
\hline $\begin{array}{c}\text { Uji } \\
\text { Kesamaan } \\
\text { Pretes }\end{array}$ & thitung & ttabel & Sig & Keterangan \\
\hline Uji t & $-0,807$ & 1.67 & 0,422 & $\begin{array}{c}\text { Tidak } \\
\text { berbeda }\end{array}$ \\
\hline
\end{tabular}

Berdasarkan pengujian kesamaan kemampuan awal dengan hasil thitung $-0,807$ dan signifikansi sebesar $0,422\left(t_{\text {tabel }}=1,67, \alpha\right.$ $=0,05)$. Hasil ini menunjukkan bahwa $-\mathrm{t}_{\text {tabel }}$ $\leq \mathrm{t}_{\text {hitung }} \leq \mathrm{t}_{\text {tabel }}$ dan nilai signifikansi lebih besar dibandingkan 0,05. Berdasarkan hasil tersebut disimpulkan bahwa tidak ada perbedaan kemampuan awal dalam keterampilan berpikir kritis di kelas eksperimen dengan kelas kontrol atau dengan kata lain kedua kelas memiliki kemampuan awal yang sama.

\section{Postes Keterampilan Berpikir Kritis}

Deskripsi data yang disajikan dalam penelitian ini terdiri dari nilai keterampilan berpikir kritis kelas eksperimen diajarkan dengan pembelajaran inkuiri terbimbing dan kelas kontrol diajarkan dengan pembelajaran konvensional diberikan tes keterampilan berpikir kritis untuk melihat apakah 
terdapat pengaruh model pembelajaran inkuiri terbimbing terhadap keterampilan berpikir kritis siswa. Adapun data postes keterampilan berpikir kritis kelas kelas konvensional dan inkuiri terbimbing dapat ditunjukkan pada Gambar 2.

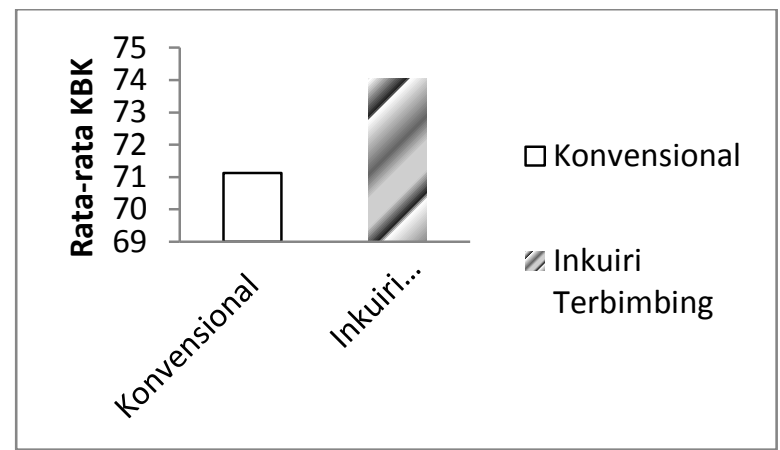

Gambar 2. Grafik Postes Keterampilan Berpikir Kritis Kelas konvensional dan Inkuiri Terbimbing.

Menganalisis perbedaan dapat dilakukan dengan membandingkan rata-rata keterampilan berpikir kritis kedua kelas. Analisis tiap item indikator keterampilan berpikir kritis siswa yang diajarkan dengan model konvensional dan inkuiri terbimbing dapat dilihat pada Tabel 4 .

Tabel 4. Analisis Indikator Keterampilan Berpikir Kritis

\begin{tabular}{|c|l|c|c|}
\hline No & $\begin{array}{c}\text { Item } \\
\text { Keterampilan } \\
\text { Berpikir Kritis }\end{array}$ & Konvensional & $\begin{array}{c}\text { Inkuiri } \\
\text { terbimbing }\end{array}$ \\
\hline 1 & Menganalisis & 6,79 & 7,82 \\
\hline 2 & Mensintesis & 7,08 & 7,39 \\
\hline 3 & $\begin{array}{l}\text { Memecahkan } \\
\text { masalah }\end{array}$ & 7,18 & 7,18 \\
\hline 4 & $\begin{array}{l}\text { Membuat } \\
\text { simpulan }\end{array}$ & 7,32 & 7,13 \\
\hline
\end{tabular}

Analisis keterampilan berpikir kritis siswa yang diajarkan dengan model konvensional dan inkuiri terbimbing dapat dilihat dari Gambar 3.

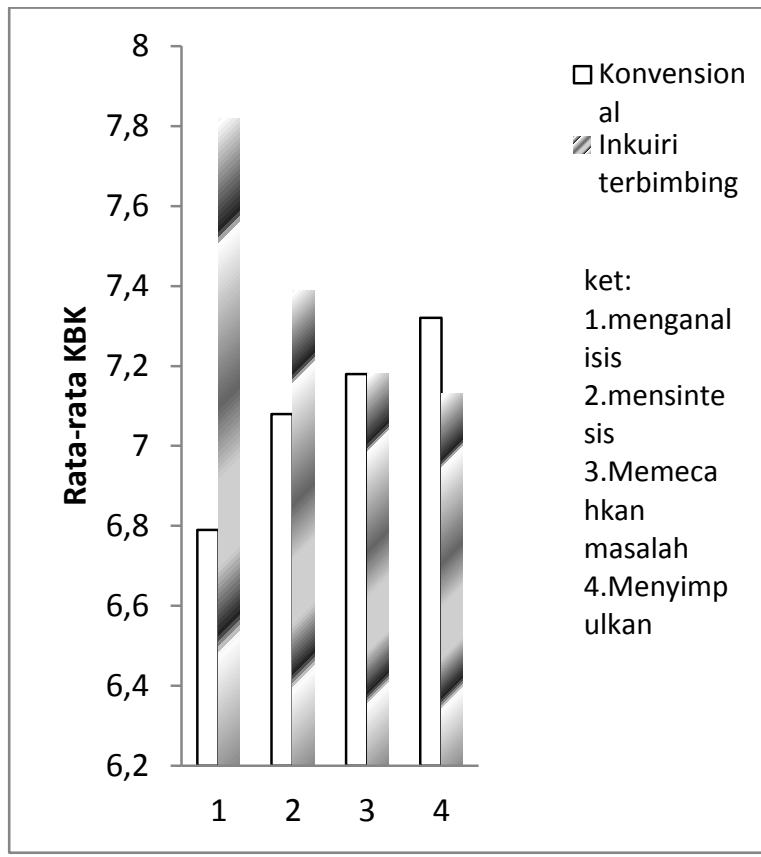

Gambar 3.Analisis Indikator Keteramprilan Berpikir Kritis

Gambar 3 menunjukan analisis perbedaan indikator keterampilan berpikir kritis. Siswa yang diajarkan dengan model inkuiri terbimbing memperoleh rata-rata yang lebih baik pada indikator menganalisis dan mensintesi dibanding siswa yang diajarkan dengan model konvensional.

\section{Hipotesis Keterampilan Berpikir Kritis}

Pengujian hipotesis ini dilakukan dengan uji hipotesis satu pihak menggunakan uji t dengan bantuan software SPSS 16.0. Sebelum melakukan uji $\mathrm{t}$ dilakukan uji prasyarat (uji normalitas dan 
homogenitas) terhadap data postes keterampilan berpikir kritis. Uji normalitas untuk mengetahui kedua kelas berdistribusi secara normal dengan menggunakan SPSS 16.0. Uji normalitas hasil belajar dapat ditunjukkan pada Tabel 5.

Tabel 5. Uji Normalitas Postes Keterampilan Berpikir Kritis

\begin{tabular}{|c|c|c|c|c|c|}
\hline No & Kelas & $\begin{array}{c}\text { L- } \\
\text { hitung }\end{array}$ & Sig. & $\mathbf{L}_{\text {tabel }}$ & Ket. \\
\hline 1 & Konvensional & 0,117 & 0,200 & 0,174 & Normal \\
\hline 2 & $\begin{array}{c}\text { Inkuiri } \\
\text { Terbimbing }\end{array}$ & 0,129 & 0,108 & 0,174 & Normal \\
\hline
\end{tabular}

Kelas konvensional diperoleh nilai Lhitung sebesar 0,117 dan signifikansi sebesar $0,200\left(\mathrm{~L}_{\text {tabel }}=0,174, \alpha=0,05\right)$. Hasil ini menunjukkan bahwa $\mathrm{L}_{\text {hitung }}<\mathrm{L}_{\text {tabel }}$ dan signifikansi lebih besar dari 0,05, maka data pada kelas konvensional adalah berdistribusi normal.

Uji kesamaan varians dan rata-rata nilai postes dilakukan dengan test of homogenety of variance menggunakan SPSS 16.0. Hasil pengujian dapat ditunjukkan pada Tabel 5.

Tabel 6. Uji Homogenitas Postes \begin{tabular}{|c|c|c|c|c|}
\multicolumn{5}{c|}{ Keterampilan Berpikir Kritis } \\
\hline $\begin{array}{c}\text { Uji } \\
\text { Homogenitas }\end{array}$ & $\mathbf{F}_{\text {hitung }}$ & $\mathbf{F}_{\text {tabel }}$ & Sig & Keterangan \\
\hline $\begin{array}{c}\text { Berdasarkan } \\
\text { rerata }\end{array}$ & 0.233 & 1.90 & 0.631 & Homogen \\
\hline
\end{tabular} Hasil pengujian memperlihatkan nilai $F_{\text {hitung }}$ untuk pretes keterampilan berpikir kritis 0,233 dengan signifikansi
0,631 $\left(\mathrm{F}_{\text {tabel }}=1,90, \alpha=0,05\right)$. Berdasarkan hasil tersebut $\mathrm{F}_{\text {hitung }}<\mathrm{F}$ tabel dan signifikan hitung lebih besar dibandingkan $\alpha=0,05$ sehingga dapat disimpulkan data postes keterampilan berpikir kritis kelas konvensional dan kelas inkuiri terbimbing memiliki varians yang sama atau homogen. Uji normalitas dan uji homogenitas dari kedua kelas sampel dibutuhkan sebagai uji prasyarat untuk melakukan pengujian hipotesis postes keterampilan berpikir kritis (uji t). Karena data kedua kelas normal dan homogen maka dapat dilakukan uji t postes keterampilan berpikir kritis dari kedua kelas sampel.

Pengujian hipotesis postes keterampilan berpikir kritis dilakukan dengan uji t sampel bebas menggunakan SPSS 16.0. Hasil pengujian dapat ditunjukkan pada Tabel 6.

Tabel 7. Uji Hipotesis Postes Keterampilan Berpikir Kritis kelas Konvensional dan Inkuiri Terbimbing.

\begin{tabular}{|c|c|c|c|c|}
\hline $\begin{array}{c}\text { Uji } \\
\text { Kesamaan } \\
\text { Pretes }\end{array}$ & thitung & $\mathbf{t}_{\text {tabel }}$ & Sig & Keterangan \\
\hline Uji t & 2,270 & 1.67 & 0,026 & $\begin{array}{c}\text { Signifikan } \\
\text { berbeda }\end{array}$ \\
\hline
\end{tabular}

Berdasarkan pengujian hipotesis keterampilan berpikir kritis dengan hasil $t_{\text {hitung }}$ 2,270 dan signifikansi sebesar 0,026 $\left(\mathrm{t}_{\text {tabel }}=1,67, \alpha=0,05\right)$. Hasil ini menunjukkan bahwa $t_{\text {hitung }}>$ tabel dan nilai 
signifikansi lebih kecil dibandingkan 0,05. Berdasarkan hasil tersebut disimpulkan bahwa ada perbedaan postes keterampilan berpikir kritis di kelas inkuiri terbimbing dengan kelas konvensional dengan hasil keterampilan berpikir kritis kelas inkuiri terbimbing lebih baik dari kelas konvensional.

\section{Berdasarkan Tabel 4.13 maka} diberikan kesimpulan yang terkait dengan hipotesis penelitian ini, maka hipotesis statistik yang diperoleh adalah hipotesis yang diajukan $\mathrm{H}_{\mathrm{a}}$ diterima, yaitu Ada pengaruh model pembelajaran inkuiri terbimbing dan model pembelajaran konvensional terhadap keterampilan berpikir kritis siswa, karena $\alpha=0,05>\operatorname{sig} 0.026$ dan $t_{\text {hitung }}>t_{\text {tabel }}(2,27>1,67)$.

Peningkatan keterampilan berpikir kritis dilakukan perhitungan nilai peningkatan rata-rata atau $\mathrm{N}$-gain kelas inkuiri terbimbing dan konvensional. Berdasarkan perhitungan nilai N-gain kelas inkuiri terbimbing diperoleh peningkatan sebesar 0,727 pada kategori sedang, pada kelas konvensional diperoleh peningkatan sebesar 0,613 pada kategori sedang. Hasil perhitungan N-gain ditunjukan pada Tabel 8.

Tabel 8. Hasil Perhitungan N-gain Keterampilan Berpikir Kritis

\begin{tabular}{|c|c|c|c|}
\hline No & Model & $\begin{array}{c}\text { N-gain } \\
\text { Keterampilan } \\
\text { Berpikir } \\
\text { Kritis }\end{array}$ & Keterangan \\
\hline & Inkuiri & & Tinggi \\
\hline 1 & Terbimbing & 0,727 & Sedang \\
\hline
\end{tabular}

Pengaruh Model Pembelajaran Inkuiri Terbimbing dan Konvensional Terhadap Keterampilan Berpikir Kritis Siswa

Pembelajaran model inkuiri terbimbing siswa diajak untuk aktif mencari pengetahuannya sendiri. Siswa dilatih untuk menemukan fenomena-fenomena fisika dari proses yang dirancang oleh guru. Peran guru sebagai motivator terlihat jelas saat guru mengajak siswa untuk mengidentifikasi dan merumuskan masalah. Sebagai vasilitator guru memberi ruang kepada siswa melakukan percobaan dan pengumpulan data, guru memberi ruang kepada siswa melakukan tanya jawab dan memberi kesempatan siswa memaparkan hasil diskusinya. Pada setiap percobaan siswa memperoleh kecakapan dalam menggunakan alat ukur listrik. Serangkaian kegiatan psikomotorik yang dilakukan siswa dengan semangat dan mampu membangun struktur kognitif dalam memori jangka panjang.

Tugas utama guru adalah memilih masalah yang perlu disampaikan kepada siswa untuk dipecahkan. Tugas-tugas 
berikutnya dari guru adalah menyediakan sumber belajar bagi siswa dalam pemecahan masalah. Dalam model pembelajaran inkuiri terbimbing, penyajian masalah diawali dengan penjelasan suatu peristiwa yang penuh teka-teki sehingga secara individu akan termotivasi menyelesaikan teka-teki tersebut. Dalam kondisi demikian siswa merasa termotivasi dan guru akan membimbing siswa melakukan suatu pencarian dan penyelidikan secara disiplin.

Model pembelajaran inkuiri terbimbing dapat lebih membiasakan siswa untuk membuktikan suatu materi pelajaran, membuktikan dengan melakukan penyelidikan sendiri oleh siswa yang dibimbing oleh guru. Penyelidikan dapat dilakukan oleh siswa baik didalam ruangan seperti dilaboratorium maupun dilapangan terbuka kemudian hasil penyelidikan dianalisis oleh para siswa menggunakan buku-buku referensi yang mendukung tentang materi yang diselidiki. Dengan menggunakan model inkuiri terbimbing ini pengembangan ranah kognitif siswa lebih terarah dan dalam kehidupan sehari-hari dapat diaplikasikan secara motorik. Keterampilan yang diperoleh melalui serangkaian proses sains membuat siswa aktif membangun pengetahuannya.
Keterampilan Berpikir kritis adalah kemampuan siswa untuk menerapkan metode ilmiah dalam memahami, mengembangkan dan menemukan ilmu pengetahuan. Keterampilan berpikir kritis sangat penting bagi setiap siswa sebagai bekal untuk menggunakan metode ilmiah dalam mengembangkan sains serta diharapkan memperoleh pengetahuan baru atau mengembangkan pengetahuan yang telah dimilikinya. Dengan pembelajaran inkuiri terbimbing, keterampilan keterampilan berpikir kritis siswa dibangun sedemikian hingga memcapai tingkat yang optimum.

Berbeda halnya dengan model konvensional yang mengedepankan proses latihan kepada siswa. Pengetahuan diajarkan dengan dengan cara melatih siswa, kecenderungan siswa dituntut menghafal pengetahuan yang diberikan guru. Serangkaian kegiatan dilakukan secara instruksional tanpa memberi kesempatan siswa mencari sendiri pengetahuanya. Serangkaian kegiatan instruksional ini mengkondisikan pada situasi kelas yang diam, tanpa aktivitas siswa, tanpa kegiatan tanya jawab, siswa hanya memperhatikan penjelasan guru. Kegiatan siswa yang pasif tersebut berdampak kepada lemahnya penyerapan pengetahuan oleh siswa. 
Pengetahuan yang diperoleh tidak bertahan lama dalam memori siswa, sehingga keterampilan berpikir kritis siswa pun menjadi rendah.

Keterampilan berpikir kritis siswa yang diajarkan dengan model inkuiri terbimbing menunjukan hasil yang baik. Siswa mampu menjawab tes hasil belajar pada semua indikator keterampilan berpikir kritis dengan baik. Jika dibandingkan dengan hasil belajar siswa yang diajarkan dengan model pembelajaran Konvensional yang memperoleh hasil belajar yang lebih rendah. Maka dapat disimpulkan bahwa terdapat perbedaan keterampilan berpikir kritis siswa antara siswa yang diajarkan dengan model inkuiri terbimbingdan model konvensional. Dimana keterampilan berpikir kritis siswa yang diajarkan dengan mode inkuiri terbimbing lebih baik dari keterampilan berpikir kritis siswa yang diajarkan dengan model konvensional.

\section{SIMPULAN}

Berdasarkan hasil penelitian, pengolahan dan pembahasan yang telah dilakukan, maka dapat disimpulkan bahwa model pembelajaran inkuiri terbimbing yang diterapkan pada kelas eksperimen berpengaruh secara signifikan dalam meningkatkan keterampilan berpikir kritis dibandingkan dengan pembelajaran konvensional yang diterapkan pada kelas kontrol.

\section{DAFTAR PUSTAKA}

Angelo. A. T. (1995). Beginning The Dialogue Thoughts on Promoting Critical Thingking. Boston College.

Costa, A.L. (1985). Goal for Critical Thingking Curriculum. In Costa A.L. (ed). Developing Minds A. Resource Book for Teaching Thingking. Alexandria: ASCD

Efendi. (2010). Mengapa Prestasi Indonesia Redup di Olimpiade Fisika. Kompas: Jakarta

Ennis, (1996). Critical Thinking. New Jersey: Prentice Hall, Uper Saddle River.

Sugiharto. (2001). Statistika Untuk Penelitian. Bandung: Alfabeta

Trowbrige \& Bybee. (1990). Becoming a secondary school Science Teacher Ohio : Merrill Publishing Company. 